\title{
IMPACTS OF INTENSIVE AGRICULTURE ON CURRENT RURAL LANDSCAPE - A CASE STUDY FOR SOUTH MORAVIAN LANDSCAPE, CZECH REPUBLIC
}

\author{
Petra Fukalová1, Tomáš Mašíček ${ }^{1}$ \\ ${ }^{1}$ Mendel University in Brno, Faculty of AgriSciences, Zemědělská 1, 61300 Brno, Czech Republic
}

To cite this article: FUKALOVÁ PETRA, MAŠÍČEKTOMÁŠ. 2018. Impacts of Intensive Agriculture on Current Rural Landscape - A Case Study for South Moravian Landscape, Czech Republic. Acta Universitatis Agriculturae et Silviculturae Mendelianae Brunensis, 66(5): 1099-1109.

To link to this article: https://doi.org/10.11118/actaun201866051099

\begin{abstract}
The landscape in several countries of Central and Eastern Europe went through the most dramatic change in the socialist period. Agricultural land was considered only as a productive area. The size of arable land plots increased and stabilizing elements in the landscape were removed. This land consolidation of agriculture has led to the development of soil erosion. This paper presents a case study focused on comparison of landscape structure of model territory in two periods. The first period shows landscape before collectivization of agriculture, and the second one presents current landscape. The research dealt especially with evaluation of ecological stability and water erosion risk of the landscape. The identification of land use trends helps to characterize landscape of the model territory during monitored period. The following trends: decreasing area of arable land, increasing area of built-up areas and other areas and increase area of vineyards showed different character of current landscape. The evaluation of ecological stability confirmed the loss of stable landscape elements. Based on the calculated values of ecological stability coefficient, the evaluated landscape has degraded from the category of "disturbed landscape capable of self-regulation" to "devastated landscape". The results also show the vulnerability of current large plots of arable land and vineyards to water erosion.
\end{abstract}

Keywords: landscape structure, historical changes, collectivization of agriculture, erosion risk, ecological stability, South Moravia, Czech Republic

\section{INTRODUCTION}

Cultural landscapes are an expression of continuous land changes following the use and spatial demands of various societies (Antrop, 2005). Land use of agricultural landscape is dynamic and is connected with changes in the structure of patches, their spatial pattern, size or connectivity (Arx Von et al., 2002). Austad (2000) formulated several strategies for maintaining agricultural landscape values. All his strategies are focused on adapted use and functionality of the landscape based on knowledge of its historical development and past functions of landscape. To state two of them, 1.Semi-natural vegetation types should be protected and preserved. Traditional agricultural systems are valuable because they had been sustainable for centuries and can be good models for the future. 2 . More research is needed on traditional agricultural landscape as well as more applications of its results. 
Time sequence of aerial and/or satellite photos monitoring land use changes and showing all the disturbances, devastation and other parameters of landscape structure enable us to investigate developmental changes and to improve proposals of essential protective and management measures. Acquired outcomes interpreted as trends in combination with social, political and economic conditions are used as an important source of information for landscape planning. Not only current situation but also historical trends of landscape development should be considered for landscape problem solving (Stejskalová et al., 2013).

From the landscape evaluation point of view, the so called matrices - areas that take up a dominant position in landscape, are very important (Forman and Godron, 1986). Some landscape ecologists evaluate the landscape changes by metrics methods as e.g. Palmer (2004). One of the most frequently used methods of landscape evaluation by metrics is the calculation of coefficient of ecological stability (Ces). There are several types of these coefficients, the calculation of which is based on the ratio of relatively ecologically stable to the areas to relatively unstable ones. Only one of them, namely the calculation according to the methodology of Agroprojekt, takes into account the different internal quality of the areas, their individual size, interconnectivity and interrelationship and can be used to compare the ecological stability of a landscape in time development, considering the different quality and structure of the particular areas in historical periods.

Stable areas are important for biodiversity, landscape character and landscape aesthetics. They create the typical character of the countryside and improve the connection of man to nature (Fábos and Ahern, 1996). Until 1945, changes in Czech landscape were not particularly obvious. From the 1950s to the present time, the structure of agricultural landscape has undergone radical and dramatic changes that resulted from political and economic upheavals. Collectivization in the 1950s was linked to the breaking of boundaries and consolidation of land. Modern technologies in agriculture began to develop along with intensification and specialization. This process, however, resulted in the decrease of the amount of scattered vegetation which fulfills an important function in preserving the ecological stability of the landscape. Along with grassy areas, a large number of trees, wetlands and floodplain meadows disappeared. Another wave of land consolidation that took place in the 1970s brought modification of the relief of landscapes by heavy machinery. This led to the disruption of runoff, a reduction of the number of plant and animal species and the development of soil erosion. Deep and dramatic changes of the Czech rural landscape during the period of socialist agriculture in the $2^{\text {nd }}$ half of the last century are described e.g. by Lipský, (2001).
Soil erosion by water is a world-wide problem. According to the European Environment Agency (EEA), 115 million hectares of European land are affected by water erosion with increasingly negative effects on soil productivity and the economic sustainability of agriculture, and damage caused by such erosion reaches over $€ 10$ billion a year (EEA, 2011).

There are various anthropogenic causes of soil erosion such as urbanization, land abandonment, overgrazing, deforestation and forest fires. These human activities influence land use changes resulting in soil erosion (Grimm et al., 2002; Nunes et al., 2010). Landscape structure and spatial organization of different land units has an impact on erosion and sedimentation on agricultural land (Van Oost et al., 2000).

$60 \%$ of agricultural land in the Czech Republic is threatened by water erosion. Additionally, experts warn that the situation will worsen with the advancing climate change - the extent of the endangered land will grow with increasing drought and torrential rain. This climatic trend is confirmed by Středová et al. (2011) who evaluated agroclimatic characteristics of normal (1961-1990) and long-term (1961-2010) period in the Czech Republic.

Collectivization in Eastern Europe after World War II was associated with higher yields but also with unfavorable changes in land use and cropping patterns causing acidification, soil erosion, salinization and chemical pollution (Bouma et al., 1998). Traditional pre-socialism land consolidation was mostly related to inheritance rights and land fragmentation for offspring (Niroula and Thapa, 2005). This fragmentation increased the diversity of the locality, the biodiversity (Wrbka et al., 2004) as well as soil resistance to erosion. The collectivization of agriculture in the 1950s (in the former Czechoslovakia) brought about a transformation in the spatial organization of the rural, agricultural landscape. Historically stable land tenure was substituted by vast collectivized land units (Stankoviansky et al., 2000). Unfortunately, the shape and size of the fields that did not respect land ownership, ecological principles of connectivity and soil characteristics were major and the only criterion in land consolidation. These land organization changes and other environmentally unfriendly activities affected the landscape susceptibility to soil erosion, fluvial slope processes as well as the marked geometric landform changes. (Stankoviansky et al., 2000). Land use changes and land reforms in the Czech Republic, explained in detail, on the complicated historical context background can be found in Sklenička and Šálek (2008).

Not only the spatial organization of land units from the collectivization period mentioned above, but also the nature of terrain, water draining from the CR and mainly agricultural management have caused the water erosion situation in the Czech Republic. 
Millions of tons of soil are lost from Czech fields every year especially due to bad land management.

There are several approaches which can be used to assess the soil erosion risk. The most widely used is the Wischmeier and Smith's Universal Soil Loss Equation (USLE), developed in 1978 and applied to different territorial contexts characterized by specific climate regime, soil type and topography. The USLE model estimates the annual soil loss per unit area on the basis of soil, vegetation and climate variables including soil erodibility, rainfall intensity, slope length and steepness, land-use and management (Renard et al., 1991). Vegetation, geology and land use are key variables in the USLE model (Nasiri, 2013).

The aim of this paper is to assess the importance of landscape changes related to the use of land for the ecological stability of typical agricultural landscape and the risk of water erosion associated with these changes in landscape structure using a case study. The case study looks into two forms of land use of two major historical periods with significant landscape changes (period before and after collectivization), especially changes in the structure of agricultural land. Water erosion risk is evaluated in the South Moravia Region, which has been suffering from drought in the recent years. Drought leads to a higher susceptibility of soil to erosion.

\section{MATERIALS AND METHODS}

\section{Characteristics of the study area}

Evaluated territory Žabčice with the land area of 817 ha is located in South Moravia (the Czech Republic, Central Europe), GPS location: 49.011598N, 16.602572E (Fig. 1). The territory of this land is flat and the altitude ranges from $178-218 \mathrm{~m}$ a.s.l.

In terms of geomorphological classification of the Czech Republic the model territory belongs to Outer Carpathian Depressions system which is the part of Western Carpathians province. The geological structure of the area of interest is mainly influenced by Neogene fluvial deposits. In the western part of the area, there is a protected deposit area where gravel-sand pits are being mined.
The soils are of different compositions, ranging from sandy soils, being the most frequent type, to clayey soils. The most frequent ones are genetic soil types of chernozem, slightly podzolic turf soil and alluvial gley soil (Hrnčiarová et al., 2009). The territory is located in the South Moravian region with typical dry continental climate. Dryness of the climate is increased by winds that cause large evaporation of soil moisture. According to Quitt's climatic classification type Cfb, according to Koppen (CFB-climate type of temperate deciduous forests) Žabčice falls into the warm area (T4) which is characterized by very long, (very) hot and (very) dry summers, warm and very short transitional period, short, moderately warm and dry winter with very short duration of snow cover (Quitt, 1971). The main crops cultivated in this territory are: winter wheat, spring and winter barley, silage corn, corn for grain, lucerne (alfalfa), sorghum. Cultivation of cherries and grapevine of quality varieties is typical for this area.

\section{Preparation of underlying data for evaluation of landscape structure, map processing}

Orthophotomaps and maps (M 1:10 000) provided by the Czech Surveying and Cadastre Office (CSDO) and Map data of Land Parcel Identification System (LPIS) (Map data @ Ministry of Agriculture, www.eagri.cz) displaying the current state of land use were used for the assessment of land use in 2017. A detailed field survey of the selected area was also needed. In addition, digitized archival aerial photographs of the model area provided by MGHI Dobruška (Military Geographical and Hydrometeorological Institute in Dobruška) were used to assess the historical status of the agricultural landscape structure (1953). These archival aerial photos were georeferenced on the basis of ortophotomap connected via WMS into S-JTSK Krovak East North coordinate system. Maps of the Land cadastre and Land register recording the state of land tenure up to almost 1964 were used for better interpretation of archival black and white aerial photographs from 1953 and correct allocation of the land use categories (Fukalová, Pokladníková, 2010). Old postcards and photographs from archives also served as important materials. Definition of

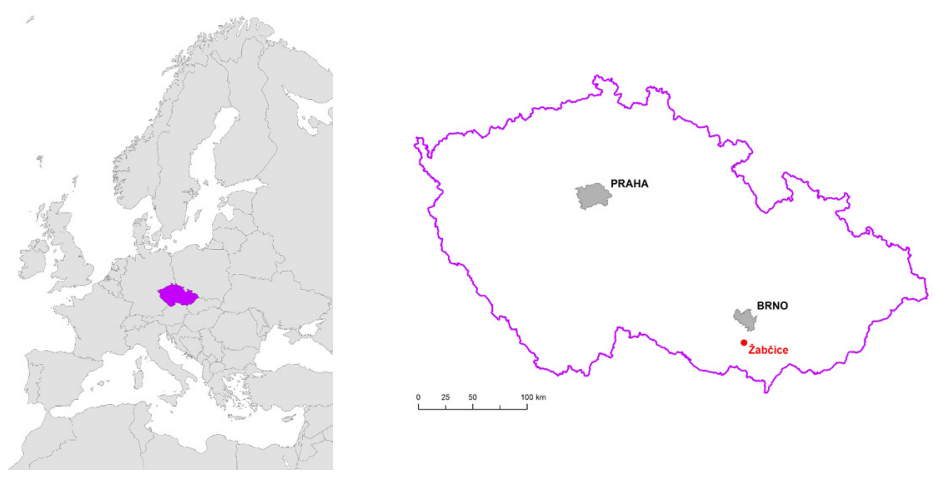

1: Location of the model territory, Czech Republic 


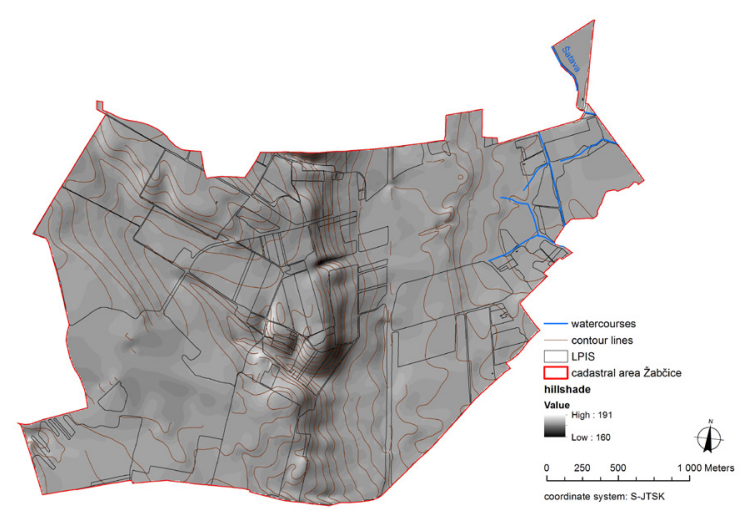

2: Model territory with shaded relief, current LPIS blocks and watercourses

land use categories is necessary to detect changes in land use in different time periods. The land use categories have been identified as an outcome of interpretation of maps and aerial photographs. Data processing and all analyses were realized with the use of ArcGIS 10.4 (ESRI).

\section{Calculation of $\mathbf{C}_{\mathrm{ES}}$}

Selected methodology of calculation of $\mathrm{C}_{\mathrm{ES}}$ uses the division of landscape segments into groups according to their quality (degree of ecological stability). The degree of ecological stability means the significance of the landscape segment for given ecosystem. When determining significance for ecological stability (SES), state of the individual landscaping elements that occur in the surveyed area is taken into account and consideration. The scale of significance of an element for the territory and its ecological stability moves ascending within the scale of $0-5$.

In order to determine the quality level of individual land categories of land use that are necessary to calculate the ecological stability coefficient according to Agroprojekt methodology, it is advisable to use Classification of Landscape Components according to their ecological stability (Löw, 1995).

$C_{e s}=\frac{1.5 A+B+0.5 C}{0.2 D+0.8 E}$

- $A=$ percentage of area falling within the 5th quality grade (the best, SES 5)

- $B=$ percentage of area falling within the 4th quality grade (SES 4)

- $\mathrm{C}=$ percentage of area falling within the 3th quality grade (SES 3)

- $\mathrm{D}=$ percentage of area falling within the 2nd quality grade (SES 2)

- $\mathrm{E}=$ percentage of area falling within the 1st quality grade (the worst, least stable, SES 1 and 0 i.e. arable land, large-scale vineyards and orchards, heavily polluted water areas and streams, built-up areas and other areas).

$\mathrm{C}_{\mathrm{es}} \leq 0.1$ devastated landscape
$0.1<\mathrm{C}_{\mathrm{es}}<1.0$ disturbed landscape capable of self-regulation

$\mathrm{C}_{\mathrm{es}}=1.0$ balanced landscape

$1.0<\mathrm{C}_{\mathrm{es}}<10.0$ landscape with predominant natural component

$\mathrm{C}_{\mathrm{es}} \geq 10.0$ natural landscape or one close to nature Classification of individual areas and categories of land use according to the degree of ecological quality is assessed individually on a case-by-case basis, based on knowledge of local conditions. However, it carries a considerable risk of subjective evaluation of the author. Several factors can be taken into account such as size, structure and internal quality influenced by technologies used (fertilization, chemistry used, mechanization, varietal structure), however, this leads to considerable prediction of the calculation.

\section{Preparation of underlying data for evaluation of soil erosion risk, map processing}

All operations leading to soil erosion risk evaluation including data preparation, data processing and analysis were processed digitally using ArcGIS 10.4 (ESRI), USLE2D and LS-converter software.

Water erosion risk was evaluated on the basis of the same input data for GIS processing as landscape changes: orthophotos for the present state - 2017 and archival aerial photos used for the historical period - 1953. Digital vector layer of Žabčice territory comes from the Czech Republic digital vector geodatabase ArcČR 500 (ARCDATA PRAHA, 2016, www.arcdata.cz). Map data of Land Parcel Identification System (LPIS) (Map data (C) Ministry of Agriculture, www.eagri.cz) displaying the current state of land use (vineyards, orchards, arable land, permanent grassland) was used for the evaluation of current erosion risk (in 2017).

Land use categories of arable land, permanent grassland, vineyards and orchards were separated by roads with ditches, greenbelts, forests, watercourses or other interruption of slope length along the fall line. Land categories reaching beyond the model territory boundary were also included as they influence erosion as well. Spatial delimitation 
of the land use categories mentioned above was expressed by vector layer in ArcGIS. Based on this layer, appropriate calculated USLE factors were displayed as well as potential soil loss due to water erosion including erosion risk levels of individual land units.

\section{Calculation and evaluation of water erosion risk using USLE model}

Soil erosion risk was assessed for two time profiles $(1953,2017)$ using the original methodology - the universal soil loss equation (USLE) (Wischmeier and Smith, 1978). The methodology for calculation all factors of the USLE equation is described in Mašíček et al. (2017).

Since the aim of the study was to assess the influence of the change in spatial arrangement of soil blocks and the structure of the crops in the compared periods, identical values of $\mathrm{R}$ and $\mathrm{K}$ factors were deliberately used in the calculation. In the case of factor $R$, the same value $(R=10)$ was used for both periods irrespective of the change in character of torrential precipitation. The factor $\mathrm{K}$ was determined on the basis of the soil ecological units (BPEJ) of the digital layer called BPEJ (Janeček et al., 2012).

Two USLE factors (C and $\mathrm{P}$ ) are very important for comparison of soil erosion risk in historical point of view. The $\mathrm{C}$ factor value can be determined according to the average crop representation in the given locality using $\mathrm{C}$ factor values for individual crops by Janeček et al., 2012 (Tab. I) The average share of the crops cultivated in 1953 was found from the manuscript of Agriculture Enterprise Žabčice in the years 1925-2000. C factor values presented by the vector layer were divided into three categories (permanent grassland - 0.005, orchards and vineyards -0.45 , arable crops - for $1953-0.16$, for $2015-0.29$ ). The resulting $C$ factor value for arable crops was expressed by the weighted average of the product of these values and the area coverage of each crop. As for P factor, if the measures are not applied on a particular piece of land and the conditions are not met, the value of factor $\mathrm{P}=1$. For the time period of the 1950's, considering the contemporary organization (plotting) of arable land (alternating narrow strips of cultivated crops on arable land) factor value $\mathrm{P}=0,3$ was established according to the methodology by Janeček et al. (2012) by the character of the crop structures (namely the root crops with multi-year forage crops). For the current period characterized by large soil blocks with one type of cultivated crop, factor $\mathrm{P}=1$ was used. Contour planting was not taken into account since it is not applicable to all plots.

Soil loss tolerance is determined on the basis of soil depth (Janeček et al., 2012). Soils in the area of interest are moderately deep $(30-60 \mathrm{~cm})$ and deep

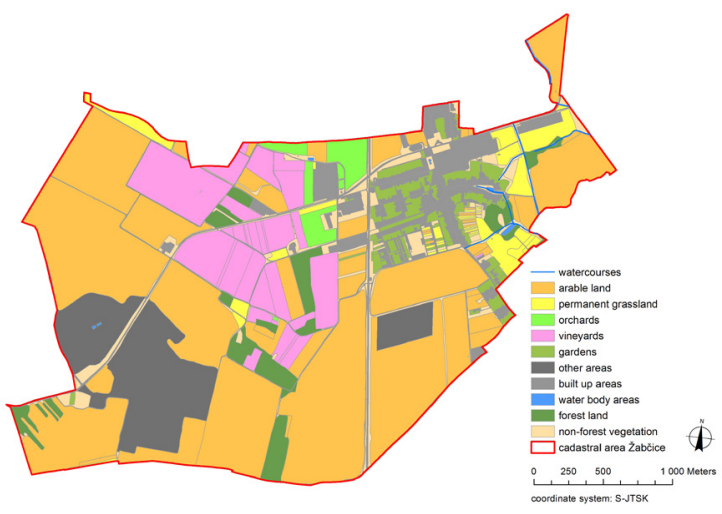

3: Land use in 1953 in Žabčice territory

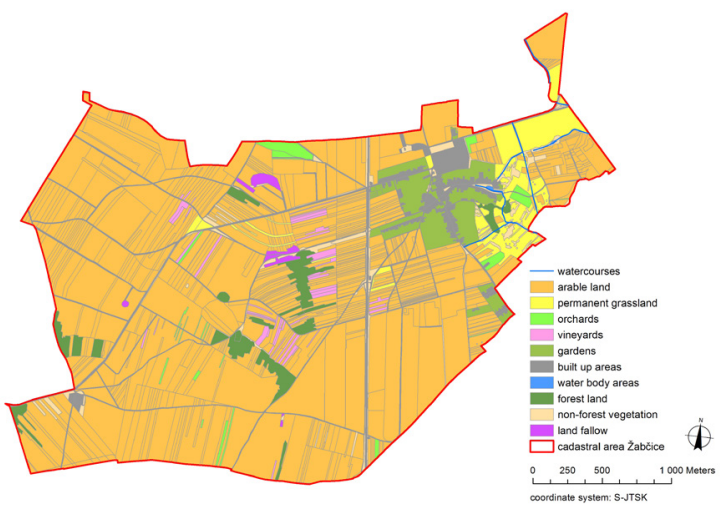

4: Land use in 2017 in Žabčice territory 
(over $60 \mathrm{~cm}$ ), the soil loss tolerance is therefore 4 t. ha-1 per year.

More comprehensive description of such operations and analysis in ArcGIS is described in the publications of Longley et al. (2011), Schmidts (2013).

\section{RESULTS AND DISCUSSION}

\section{Land use changes evaluation}

Eleven categories of land use were defined for comparison of land use in the evaluated periods 1953 and 2017 (Tab. I). The agricultural land was defined as landscape matrix in both periods because it dominates and influences the dynamics of the landscape the most. Arable land occupies the largest area of agricultural land also in both periods. The most important changes are visible on the areas of land use category of arable land (decrease), vineyards, built up areas and other areas (increase) (see Fig. 3 and 6).

Arable land occupied about $78 \%$ of total study area in 1953 and at present it covers about 50\%. Vineyards accounted for $1.5 \%$ in 1953 while they are currently taking up almost $10 \%$ of the area, however, for example in 2007 it was even $13.6 \%$. Built-up and other areas covered $4.4 \%$ in 1953 , now they reach $17.4 \%$ of the area.

Areas of other land use categories in percentage of total study area are included in Tab. I which also states their change during the analyzed period.

Although the area of arable land decreased, its structure has a completely different character at present. While in 1953 it was usually divided into small fields (narrow strips of arable land) sown by various types of crops and more densely intersected by a network of roads (Fig. 3), these days it is made up of large, integral soil blocks sown by one crop that originated during the period of socialism (Fig. 4).

This is evidenced by the comparison of the area sizes and their count. The maximum size of one arable land area was 16.7 ha in 1953 and 59.5 ha in 2017. The average size of one area of arable land in 1953 was 0.7 ha and it increased to 9.6 ha in 1917. The number of arable land plots in 1953 was 878, in 2017 it was 42 . The area of vineyards increased by $9.8 \%$, the number of the vineyards plots was 50 with the average area 0.2 ha in 1953 while their number in 2017 was 30 with average area 3 ha. Former structure of vineyards formed into narrow plots dispersed on the agricultural land of the model territory has changed into large plots. Stránská, Havlíček (2008) also pointed out the different structure of spatial organization of vineyards in the South Moravia Region.

The land use analysis shows a growing trend of built-up and other areas and loss of arable land, which is characteristic for the whole CR, see Tab. II. Growing trend of vineyards is documented by the UKKZUZZ (2017) which shows an annual increase in vineyard area from 2013 by $0.6 \%$. This increase is evident especially in the Moravian wine-growing region where there are over $94 \%$ of all

\section{Ecological stability evaluation}

The ecological stability degrees were assessed on the basis of the field survey and methodology of Míchal (1994, pp. 231-232). The individual stages of this six-digit classification (0-5) are characterized in Tab. III.

I: Change in land use in percentage of total model area in both monitored periods

\begin{tabular}{l|c|c|c}
\hline \multicolumn{1}{c|}{ Land use } & 1953 [\%] & 2017 [\%] & change [\%] \\
\hline Arable land & 77.8 & 49.4 & -28.4 \\
Permanent grassland & 4.7 & 3.9 & -0.8 \\
Orchards & 1.2 & 3.3 & 2.1 \\
Vineyards & 1.5 & 11.3 & 9.8 \\
Gardens & 3.8 & 2.7 & -1.1 \\
Other areas & 0.0 & 9.3 & 9.3 \\
Built up areas & 4.4 & 12.5 & 8.1 \\
Water body areas & 0.1 & 0.4 & 0.3 \\
Forest land & 2.9 & 3.9 & 1.0 \\
Non-forest vegetation & 3.1 & 3.3 & 0.2 \\
Land fallow & 0.5 & 0.0 & -0.5 \\
\hline
\end{tabular}

Non-forest vegetation includes scattered vegetation, grassy areas, line trees and shrubs along the roads and water courses

II: Land use development in the Czech Republic (1948-2016)

\begin{tabular}{l|c|c|c|c|c}
\hline \multicolumn{1}{c}{ Land use } & $\mathbf{1 9 4 8}$ & $\mathbf{1 9 9 0}$ & $\mathbf{2 0 0 0}$ & \multicolumn{2}{c}{$\mathbf{2 0 1 0}$} \\
\hline Arable land & 49.9 & 41.0 & 39.1 & 38.1 & 37.6 \\
Vineyards & 0.1 & 0.2 & 0.2 & 0.2 & 0.3 \\
Orchards & 0.6 & 0.6 & 0.6 & 0.6 & 0.6 \\
Built up areas & 1.1 & 1.6 & 1.7 & 1.7 & 8.9 \\
Other areas & 2.9 & 8.6 & 8.6 & 9.0 \\
\hline
\end{tabular}

Source: Czech Office for Surveying, Mapping and Cadastre) 
III: Six-digit classification of significance for ecological stability

\begin{tabular}{ccc}
\hline degree of SES & stability character & significance for ecological stability \\
\hline 0 & unstable & without significance \\
1 & very little stable & very small significance \\
2 & little stable & small significance \\
3 & stable & medium \\
4 & very stable & high \\
5 & the most stable & exceptionally high significance \\
\hline
\end{tabular}

IV: Significance for ecological stability (SES) for particular land use categories

\begin{tabular}{lcccc}
\hline \multirow{2}{*}{ Land use } & \multicolumn{2}{c}{ 1953 } & & 2017 \\
\cline { 2 - 5 } & {$[\%]$} & SES & {$[\%]$} & SES \\
\hline Arable land & 77.8 & 1 & 49.4 & 1 \\
Permanent grassland & 4.7 & 3 & 3.9 & 3 \\
Orchards & 1.2 & 3 & 3.3 & 2 \\
Vineyards & 1.5 & 2 & 11.3 & 1 \\
Gardens & 3.8 & 3 & 2.7 & 3 \\
Other areas & 0.0 & 0 & 9.3 & 0 \\
Built up areas & 4.4 & 0 & 12.5 & 0 \\
Water body areas & 0.1 & 3 & 0.4 & 2 \\
Forest land & 2.9 & 4 & 3.9 & 3 \\
Non-forest vegetation & 3.1 & 4 & 3.3 & 3 \\
Land fallow & 0.5 & 3 & 0.2 & 3 \\
\hline
\end{tabular}

V: Erosion rate in both evaluated periods in the model territory of Žabcice

\begin{tabular}{cccccc}
\hline $\begin{array}{c}\text { Erosion rate G } \\
{\left[\text { t.ha } \text {.year }^{-1} \text { ] }\right.}\end{array}$ & \multicolumn{2}{c}{$\mathbf{1 9 5 3}$} & \multicolumn{2}{c}{$\mathbf{2 0 1 7}$} \\
\cline { 2 - 5 } & {$[$ [ha] } & {$[\%]$} & {$[$ [ha] } & [\%] \\
\hline $0.1-2.0$ & 679.6 & 97.9 & 357.7 & 65.6 \\
$2.1-4.0$ & 4.7 & 0.7 & 146.6 & 26.9 \\
$4.1-6.0$ & 1.9 & 0.3 & 30.0 & 5.5 \\
$6.1-8.0$ & 3.9 & 0.6 & 2.4 & 0.4 \\
$8.1-10.0$ & 3.0 & 0.4 & 4.1 & 0.8 \\
$10.1-12.0$ & 0.8 & 0.1 & 4.1 & 0.8 \\
\hline
\end{tabular}

The determination of significance of individual categories of land use for ecological stability took into account their size, structure, intensity of usage, nature character and internal quality (Tab.IV)

After completing the formula given in the methodology, the value of 0.2 was calculated as the coefficient of ecological stability for 1953. At that time, the landscape was already disrupted in terms of ecological stability but still capable of self-regulation. For the year 2017, a value of 0.1 was calculated, which is already the threshold for devastated landscape. These results are related to the observed trends in land use, in particular the growth of built-up areas and especially other areas (extension of sand-pit, a solar power plant), the growth of vineyards and their large-scale structure. Another unfavorable factor here was the deteriorating condition of non-forest vegetation, especially tree lines along roads.

\section{Water erosion risk evaluation}

Based on the calculated factors of the universal USLE equation quantifying water erosion caused by torrential rainfall, the mean long-term loss of soil by water erosion was calculated for the area of interest according to the methodology of Janeček et al. (2012) using GIS tools.

The results of the evaluation of the erosion ratios on agricultural land in the evaluated periods, expressed in terms of the mean value of the soil loss in t.ha $\mathrm{a}^{-1}$.year ${ }^{-1}$ for each plot are shown graphically in Fig. 5 and 6.

The average long-term loss of soil by water erosion on individual plots in the area of interest was found in both evaluated periods in the range of 0.1 to 12 t.ha ${ }^{-1}$.year ${ }^{-1}$. Tab. V quantifies the area of agricultural parcels according to their average erosion loss belonging to one of six categories of the total range defined by interval $2 \mathrm{t}$.ha ${ }^{-1}$.year ${ }^{-1}$.

In $1953,97.9 \%$ of the area of agricultural land in the area of interest Žabčice, representing 679.6 ha, saw soil loss to 2 t.ha ${ }^{-1}$.year-1. Higher erosion losses were recorded only on a negligible area represented by a tenth of a percent of the total area of agricultural land. The average loss in this period was $0.3 \mathrm{t}^{\mathrm{h}} \mathrm{ha}^{-1}$. year $^{-1}$. Due to the occurrence of moderately deep and deep soils, the permissible loss, which is 4 t.ha ${ }^{-1}$. year $^{-1}$, was not exceeded.

Year 2017 saw a decrease in the area of land with a loss of soil to 2 t.ha ${ }^{-1}$ year ${ }^{-1}$ (from $97.9 \%$ to $65.6 \%$ 
of the area) at the expense of the area of agricultural land affected by the average soil loss in the interval 2.1 up to 4.0 t.ha $^{-1}$.year ${ }^{-1}$, namely $0.7 \%$ in 1953 to $26.9 \%$ of the area in 2017. A significant increase in the area of agricultural land was also recorded in the soil loss category in 2017, 4.1 to 6.0 t.ha $^{-1}$.year ${ }^{-1}$, from $0.3 \%$ to $5.5 \%$. Considerable attention also needs to be paid to the growth of areas at risk of the highest soil loss, i.e. in the interval (range) 10.1 to 12.0 t.ha $^{-1}$. year-1.

In 1953 this loss was recorded on only 0.8 ha of agricultural land, while in 2017 it was already 4.4 ha. Even though the permissible soil loss by water erosion for moderately deep and deep soils was not exceeded in 2017, it can be stated that the increase in average soil loss to 1.5 t.ha $^{-1}$ year $^{-1}$ is significant and reflects the current trend of the agricultural landscape management.

The maps of erosion rate presented bellow (Fig. 5 and 6) show vulnerability of large areas of arable land to water erosion.

The central and north-eastern part of the assessed area can be considered as the most problematic area in terms of the increase in soil loss is. This increase can be attributed to the current size of soil blocks (expressed by $\mathrm{P}$ factor) which was more pronounced on land with higher slope in the central part of the area of interest Žabčice. This fact also corresponds to the higher LS factor values in this part of the territory. Another reason for higher values of average long-term soil loss is the change in the structure of cultivated crops, especially the increase of crop share with lower soil protection effect, expressed by higher $\mathrm{C}$ factor values on arable land. Although the meteorological conditions of the year influence values of $\mathrm{C}$ factor, e.g. the longest growing season was observed in the decade of 1971-1980 (Stehnová et al., 2016), however, the structure of cultivated crops plays the main role. In today's crop rotation process, wide-row crops such as corn are widely represented, which was not the case in the 1950s when corn was not cultivated at all. The increase in areas sown with maize, contributing significantly to the increase of soil loss by water erosion, was not eliminated by either increasing the area sown by fodder plants nor reduction of areas sown by sugar beet. In addition, an increase in acreage of areas with a higher $\mathrm{C}$ factor, such as vineyards and orchards also contributed negatively to increase of soil loss (Figs. 7 and 8).

Consequently, all results revealed that the soil structure in 1953 was more favourable in view of bypassing the risk of water erosion, mainly due to the diversity of crops grown on smaller plots, lower areas of cultures with high $\mathrm{C}$ factor (vineyards, orchards) and more abundant occurrence of non-vegetation (roads) as well vegetation (baulks) boundaries between plots.

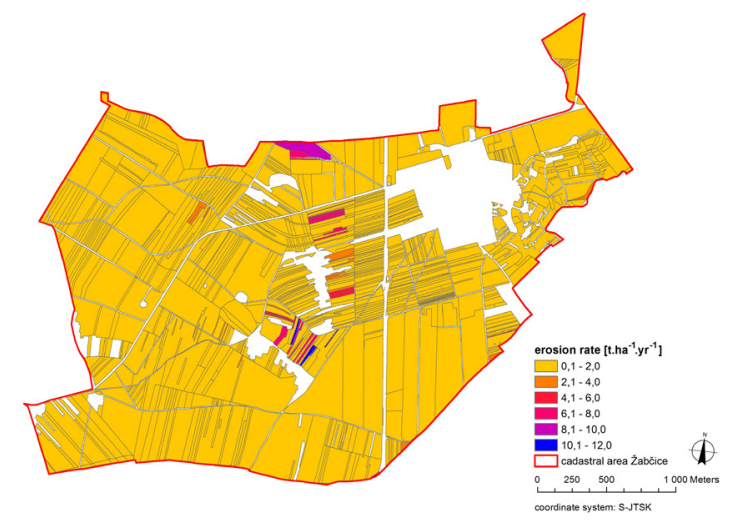

5: Erosion rate in t.ha ${ }^{-1}$ per year in Žabčice model territory in 1953

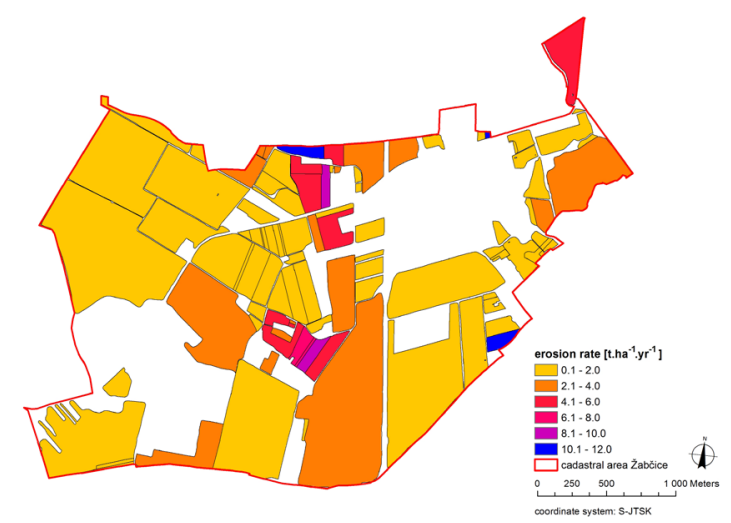

6: Erosion rate in t.ha ${ }^{-1}$ peryear in Žabcice model territory in 2017 


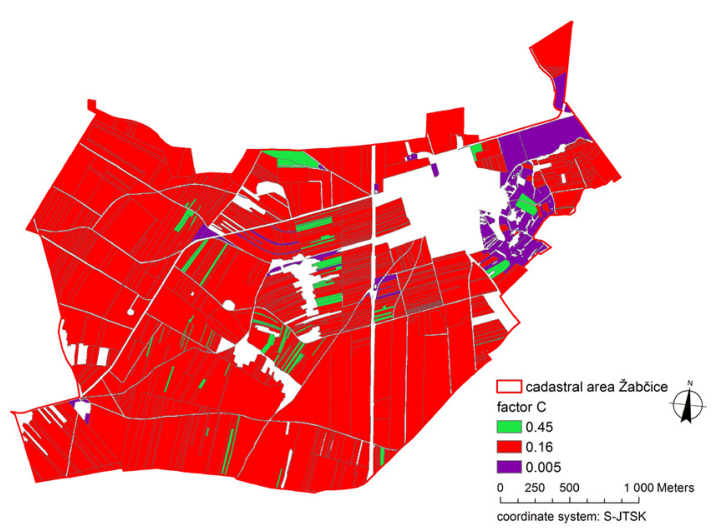

7: C factor in Žabčice territory in 1953

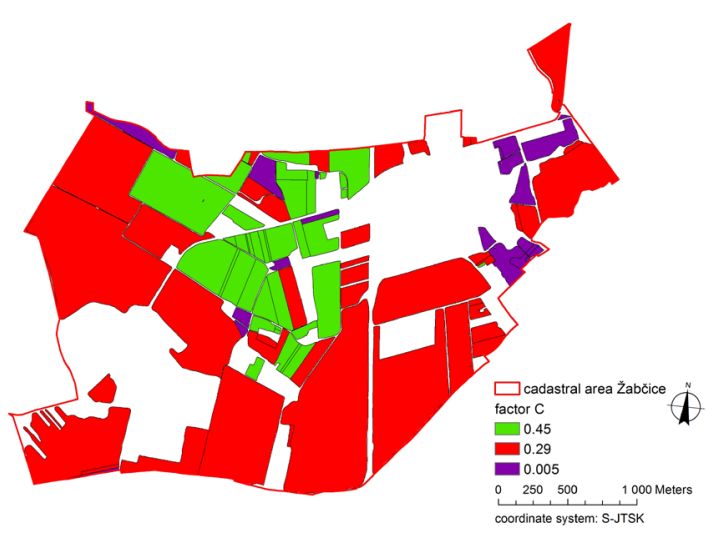

8: C factorin Žabčice territory in 2017

The area of non-forest vegetation in the area of interest did not show any significant quantitative changes, see Tab. I. According to Flekalova et al. (2008), its state and appearance have fundamentally changed. The worst growing and health conditions are evident in the surrounding areas of roads. Tree alleys, grown along roads since the 1930's, are stigmatized not only by age but also by poor maintenance. Worsening of the status or the extinction of these important elements of landscape affects not only the ecological stability of the area but also the values of the soil moisture, as the grass along the paths positively affects the reduction of the wind speed and thus prevents drying of the soil. Possibilities of assessment of non-forest vegetation (protective forest strips) of different species composition, age and construction, especially in view of their positive anti-erosion function in the conditions of South Moravia, are reported by Středa et al. (2008). Preservation and restoration of green elements are therefore very desirable, especially given that the land in Žabčice area as well as neighbouring territories are classified as soil most vulnerable to wind erosion.

Results showing higher exposure of agricultural land to water erosion at present illustrate how crucial the structure of land is (spatial organization of land units on water erosion risk). One of the aims of this study was to show that, even in a flat territory, it is possible to influence drainage conditions by a change of management in order to mitigate erosion.

\section{CONSLUSION}

The analysis of landscape structure in the period of more than 60 years presents an effective background material applicable in landscape planning and soil erosion protection. Used historical materials are, in spite of difficult and time consuming work with them, a very valuable source of unique and fundamental information for influencing the future character, functions and quality of landscape.

More attention should be paid to the study of past traditional landscapes and efforts to preserve their valuable remnants. Return to the historic landscape is not possible, however, it is possible to apply the acquired knowledge about the formerly more sustainable erosion and ecologically more stable functioning of the landscape to design projection, landscaping adjustments and general economic 
management in the area. Therefore it is necessary to study the ways how valuable elements of landscape can be preserved and become embedded functionally in the modern globalized society. Improving the state of the agricultural landscape in the CR in relation to the erosion rate could benefit from the newly prepared legislative document (Anti-erosion Decree of the Czech Republic, Act No. 344/1992 Coll., on agricultural land fund protection) which should ensure protection of $45 \%$ of Czech agricultural land by 2025. Other adjustments to the subsidy policy should also motivate the farmers to other, more soil-favourable farming practices which is a common goal of both Czech Ministries (the Ministry of Agriculture and Ministry of Environment).

The land throughout the European Community is under increasing environmental pressure that is caused and deteriorated by human activity. The lack of land protection threatens sustainability and long-term competitiveness in Europe. In addition, soil degradation has major impact on other areas of common interest in the EU, such as water protection, human health protection, climate change, nature conservation and biodiversity and food safety.

\section{Acknowledgment}

This paper was supported by National Agency for Agricultural Research of Ministry of Agriculture under the project no. QK1710197 "Optimization of methods for the assessment of vulnerability to wind erosion and proposals of protective measures in intensively exploited agricultural countryside" and project QJ1530181 "Determination of the actual values of the protective effect of vegetation in order to quantify and efficiency of erosion control of agricultural land in the Czech Republic".

\section{REFERENCES}

ANTROP, M. 2005. Why landscapes of the past are important for the future. Landscape and Urban Planning, 70(1-2): 21-34.

VONARX, G., BOSSHARD, A. and DIETZ,H. 2002. Land-use intensity and border structures as determinants of vegetation diversity in an agricultural area. Bull. Geobot. Inst. ETH, 68: 3-15.

AUSTAD, I. 2000. The future of traditional agriculture landscapes: retaining desirable qualities. In: KLIJN, J. and VOS, W. (Eds.). From landscape ecology to landscape science. Dordrecht: WLO Kluwer Academic Publ., pp. $43-55$.

BOUMA, J, VARALLYAY, G. and BATJES, N. H. 1998. Principal land use changes anticipated in Europe. Agr. Ecosyst. Environ, 67: 103-119.

EEA. 2011. The European environment - state and outlook 2010: assessment of global megatrends. European Environment Agency, Copenhagen. Luxembourg: Publications Office of the European Union.

FABOS, J. G. and AHERN, J. 1996. Greenways: The beginning of an international movement. Amsterdam: Elsevier.

FLEKALOVÁ, M., MALENOVÁ, P. and VIČANOVÁ, M. 2008. Analyses of historical development, soil moisture regime and scattered vegetation in the landscape area of UAE Žabčice. Acta Universitatis Agriculturae et Silviculturae Mendelianae Brunensis, 56(1):65-82.

FORMAN, R. T. and GODRON, M. 1986. Landscape ecology. John Wiley \& Sons, New York. 620 pp.

FUKALOVÁ, P., POKLADNÍKOVÁ, H. 2010. Land use development in c. a. Žabčice [in Czech: Vývojové trendy ve využití půdy v katastrálním územíŽabčice]. Acta Universitatis Agriculturae et Silviculturae Mendelianae Brunensis, 58(2): 69-76.

GRIMM, M., JONES, R. J. A. and MONTANARELLA. L. 2002. Soil erosion risk in Europe. European Soil Bureau Institute for Environment and Sustainability. JRC Ispra. EUR 19939 EN, () European Communities.

HRNČIAROVÁ, T., MACKOVČIN, P., ZVARA, I. et al. 2009. Landscape Atlas Of The Czech Republic. Praha: MŽP Praha.

JANEČEK, M. et al. 2012. Protection of agricultural land from erosion - methodology [in Czech: Ochrana zemédèlské puidy pred erozi - metodika]. Praha: ČZU, Praha.

LIPSKYY,Z. 2001. Present land use changes in the Czech cultural landscape: driving forces and environmental consequences. Moravian Geographical Reports, 9(2): 2-14

LONGLEY, P. A., GOODCHILD, M. F., MAGUIRE, D. J. and RHIND, D. W. 2011. Geografphic Information Systems and Science. Hoboken: John Wiley and Sons.

LŐW, J. et al. 1995. Guide to the designer of the local territorial system of ecological stability [in Czech: Rukovèt projektanta mistního územního systému ekologické stability]. Brno: Nakladatelství Doplněk.

MAŠÍČEK, T., KOZLOVSKY DUFKOVÁ, J. and ZÁMEČNÍK, T. 2017. Evaluation of erosion rates in cadastral area Rovečné using GIS tools. European Countryside, 9(1): 51-76.

MíCHAL, I. 1994. Ecological stability [in Czech: Ekologická stabilita]. $2^{\text {nd }}$ Edition. Brno: Veronica a MŽP ČR.

NASIRI, M. 2013. GIS modelling for locating the risk zone of soil erosion in adeciduous forest. J. For. Sci., 59(2): 87-91.

NIROULA, G. S. and THAPA, G. B. 2005. Impacts and causes of land fragmentation, and lessons learned from land consolidation in South Asia. Land Use Policy, 22 (4), 358-372. 
NUNES, A.N., COELHO, C.O.A.,ALMEIDA, A.C. and FIGUEIREDO, A. 2010. Soil erosion and hydrological response to land abandonment in a central Inland area of Portugal. Land Degradation and Development, 21: 260-273.

QUITT,E. 1971.Climatic regions of Czechoslovakia [in Czech: Klimatickéoblasti Československa]. Studia Geographica 16. Geografický ústav ČSAV, Brno. 84 p.

PACHECO F.A.L., VARANDAS S.G.P., FERNANDES L.S., JUNIOR R.V. 2014. Soil losses in rural watersheds with environmental land use conflicts. Sci. Total Environ., 485-486: 110-120.

PALMER, J. F. 2004. Using Spatial Metrics to Predict Scenic Perception in a Changing Landscape: Dennis, Massachusetts. Landscape and Urban Planning, 69(2): 201-218.

RENARD, K. G., FOSTER, G. R., WEESIES, G. A., PORTER, J. P. 1991. RUSLE: revised universal soil loss equation. J. Soil Water Conserv., 46(1): 30-33.

SCHMIDTS, M. 2013. Esri ArcGIS Desktop Associate: Certification Study Guide. Redlands, California: Esri Press.

SKLENIČKA, P. and ŠÁLEK, M. 2008. Ownership and soil quality as sources of agricultural land fragmentation in highly fragmented ownership patterns. Landscape Ecol., 23(3): 299-311.

STANKOVIANSKY, M., CEBECAUER, T., HANUŠIN, J., LEHOTSKÝ, M., SOLÍN, L., ŠÚRÍ, M. and URBÁNEK, J. 2000. Response of a fluvial system to large-scale land use changes: the Jablonka catchment, Slovakia. In: The Hydrology-Geomorphology Interface: Rainfall, Floods, Sedimentation, Land Use. Proceedings of the Jerusalem Conference, May 1999. IHAS Publication No. 261, pp. 153-164.

STEHNOVÁ, E. and STŘEDOVÁ, H. 2016. Phenology of sugar beet in the context of the water erosion risk. Listy cukrovarnickéa řepařské, 132(12): 380-386.

STEJSKALOVÁ,D., KARÁSEK, P., TLAPÁKOVÁ,L. and PODHRÁZSKÁ,J. 2013. Landscape Metrics as a Tool for Evaluation Landscape Structure, a Case Study of Hubenov Region, Czech Republic. Acta Universitatis Agriculturae et Silviculturae Mendelianae Brunensis, 61(1): 193-204.

STRÁNSKÁ, T. and HAVLÍČEK, M. 2008. Ecological Assessment of Landscape Development and Changes in the Ivančice Microregion (Czech Republic). Moravian Geographical Reports, 16(1): 26-36.

STŘEDA, T., MALENOVA, P., POKLADNIKOVA, H. and ROŽNOVSKY, J. 2008. The efficiency of windbreaks on the basis of wind field and optical porosity measurement. Acta Universitatis Agriculturae et Silviculturae Mendelianae Brunensis, 56(4): 281-288.

STŘEDOVÁ, H., CHUCHMA, F. and STŘEDA, T. 2011. Climatic factors of soil estimated system. In: Proceedings of International Scientific Conference on Bioclimate - Source and Limit of Social Development. Topolcianky, Slovakia. Nitra: SPU v Nitre, pp. 137-138.

ŠTĚPANEK, P., ZAHRADNIČEK, P. and FARDA, A. 2013. Experiences with data quality control and homogenization of daily records of various meteorological elements in the Czech Republic in the period 1961-2010. Idöjárás, 117(1): 123-141.

ÚKZÚZ. 2014. Annual changes in the area and composition of vineyards in the Czech Republic [in Czech: Meziroční změny ve výměře a skladbě vinic v České republice]. [online]. Central Institute for Supervising and Testing in Agriculture websites. Available at: http://eagri.cz/public/web/ukzuz/portal/trvale-kultury/ mezirocni-zmeny-ve-vymere-a-skladbe.html [Accessed: 2018, September 15].

VAN OOST, K., GOVERS, G. and DESMET, P. 2000. Evaluating the effects of changes in landscape structure on soil erosion by water and tillage. Landscape Ecol., 15: 579-591.

WISCHMEIER, W. H. and SMITH, D. D. 1978. Predicting rainfall erosion losses-a guide to conservation planning. USDA agriculture handbook no. 537. Washington, DC: US Government Printing Office.

WRBKA, T., ERB, K. H., SCHULZ, N. B., PETRSEIL, J., HAHN, C. and HABERL, H. 2004. Linking pattern and processes in cultural landscapes. An empirical study based on spatially explicit indicators. Land use Policy, 21(3): 289-306. 